\title{
Podział terytorialny Meksyku i Polski - analiza porównawcza
}

\author{
\# podział terytorialny \# Polska \# Meksyk \# ustrój \# konstytucja \\ \# kompetencje \# organy \# władza \# mieszkańcy \# terytorium \\ \# territorial division \# Poland \# Mexico \# structure \# Constitution \\ \# competences \# organ \# authority \# inhabitants \# territory
}

Podział terytorialny Polski i Meksyku ilustruje dwa odmienne systemy struktury terytorialnej. W przypadku Polski, wyróżniamy podział trójstopniowy (gminy, powiaty i województwa), natomiast w Meksyku - dwustopniowy (municypia i stany) z wyodrębnieniem stolicy Miasta Meksyk. W Meksyku wszystkie elementy struktury wymienia konstytucja, natomiast w polskim porządku prawnym tylko gmina, jako podstawowa jednostka samorządu terytorialnego, wymieniona jest w konstytucji, inne jednostki określa ustawa. Praca ma na celu ukazanie podobieństw i rozbieżności między dwoma państwami pod względem podziału terytorialnego.

The territorial division of Poland and Mexico illustrates two different systems of territorial structure. In the case of Poland, we distinguish a three-level division (municipalities, poviats and voivodships), while in Mexico, a two-stage (municipalities and states) with the separation of the Capital City. In Mexico, all elements of the structure are listed by the Constitution, while in the Polish legal order only the commune, as the basic unit of territorial self-government, is mentioned in the Constitution, other units are specified in the act. The work aims to show the similarities and discrepancies between the two countries in terms of territorial division.

Miasto. Pamięć i Przyszłość 3/2 (2018) ISSN 2543-621X

\section{OPEN ACCESS}

Citation: Musialik J., Podział terytorialny Meksyku i Polski - analiza porównawcza, „Miasto. Pamięć i Przyszłość", 3/2 (2018).

https://doi.org/10.26774/mpp.76

Editor: Jerzy Korczak

Received: October, 2018

Accepted: December, 2018

Published: December, 2018

Copyright: @ Ośrodek „Pamięć i Przyszłość" This is an open access article distributed under the terms of the Creative Commons Attribution-ShareAlike Licence, which permits unrestricted use, distribution, and reproduction in any medium, provided the original author and source are credited, with indications if any changes are made. All derivative works must be licensed under the same licence.

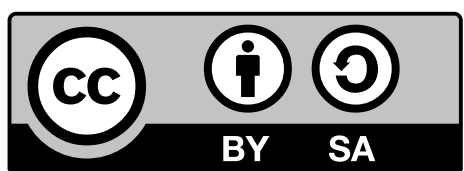


Joanna Musialik - studentka I roku studiów II stopnia na kierunku administracja na Wydziale Prawa, Administracji i Ekonomii Uniwersytetu Wrocławskiego, członek Studenckiego Koła Prawa Latynoamerykańskiego od 2014 r., wiceprezes Koła. 


\section{Konstytucyjne podstawy podziału terytorialnego Meksyku i Polski}

Podstawę podziału struktury terytorialnej Meksyku i Polski w obu przypadkach regulują konstytucje. Zgodnie z art. 40 Konstytucji meksykańskiej, naczelną konstytucyjną zasadą ustroju jest zasada federalizmu. Częściami składowymi federacji są stany, których liczbę konstytucja wylicza enumeratywnie (31 stanów i dystrykt federalny)'. Regulacja polska odmiennie odnosi się do struktury terytorialnej, zgodnie z art. 3 Konstytucji Rzeczpospolita Polska jest bowiem krajem jednolitym. Art. 164 Konstytucji RP stanowi, że podstawową jednostką podziału terytorialnego Polski jest gmina. Inne jednostki samorządu regionalnego albo lokalnego i regionalnego określa ustawa.

W tym kontekście nasuwa się już pierwsza różnica między strukturą terytorialną Meksyku i Polski, a mianowicie fakt, iż w Meksyku wszystkie elementy struktury wymienia konstytucja, natomiast w polskim porządku prawnym tylko gmina, jako podstawowa jednostka samorządu

Miasto. Pamięći Przyszłość 3/2 (2018) ISSN 2543-621X terytorialnego wymieniona jest w konstytucji, inne jednostki określa ustawa.

W Meksyku wyróżniamy dwustopniowy podział terytorialny. Ponad municypiami i stanami zostało dodatkowo wyodrębnione Miasto Meksyk (Ciudad de México), obejmujące terytorium miasta będącego stolicą Meksyku². W Polsce od 1 stycznia 1999 r. obowiązuje trójstopniowy podział terytorialny, na który składają się gminy, powiaty i województwa?.

\section{Pozycja gminy w Polsce i municypium w Meksyku}

Podstawową strukturą organizacyjną podziału terytorialnego w Meksyku jest municypium (gmina)4, które zgodnie z art. 115 konstytucji meksykańskiej rozumiane jest jako wspólnota (personal moral) mieszkańców określonego terytorium, stanowiącego część terytorium stanu. W tym znaczeniu gmina

1. I. Burgoa, Derecho constitucional mexicano, Mexico 1979, s. 23.

2. Do 2016 r. istniał Dystrykt Federalny, ale w wyniku zmiany treści art. 41 Konstytucji - zob. K. Complak, Artykut 41 Konstytucji Meksyku (brzmienie, objaśnienia, znaczenie), [w:] Dookoła Wojtek .... Księga pamiątkowa poświęcona Doktorowi Arturowi Wojciechowi Preisnerowi, red. R. Balicki, M. Jabłoński, Wrocław 2018, s. 545.

3. B. Dolnicki, Samorzad terytorialny, Kraków 2012, s. 48.

4. I. Burgoa, dz. cyt., s. 36. 
wyposażona jest w osobowość prawną i własny majątek, a rządzona przez radę wybieraną przez członków wspólnoty. Podstawowe zadanie muncypium to gospodarowanie lokalnymi zasobami w celu zaspokojenia potrzeb swoich mieszkańców. Konstytucja federalna do kompetencji municypium przekazuje kierowanie i zarządzanie sprawami o znaczeniu lokalnym. Należy tutaj m.in.

1) gospodarowanie zasobami wodnymi, problemy związane z ich wykorzystaniem dla potrzeb miejscowej ludności i gospodarki,

2) zarządzanie lokalnym handlem,

3) gospodarowanie lokalnymi parkami i ogrodami,

4) czuwanie nad przestrzeganiem spokoju i porządku publicznego,

5) wszystkie inne sprawy, które w opinii legislatyw stanowych są istotne dla zaspokojenia potrzeb miejscowej ludności w zależności od specyfiki lokalnej,

6) zgodnie z ustawami federalnymi i stanowymi zatwierdzanie i kierowanie planem zagospodarowania urbanistycznego na terytorium municypium,

7) współdziałanie w opracowywanie planów rozwoju regionalnego,

8) uczestniczenie w planowaniu i zarządzaniu terenami o znaczeniu ekologicznym.

Organem kierującym i zarządzającym municypium jest rada. Składa się ona z przewodniczącego, urzędników (radców kierujących działami administracji municypalnej) oraz urzędników zajmujących się finansami municypium (sindicos) 5 . Członkowie rady wybierani są w wyborach powszechnych i bezpośrednich. Po zakończeniu kadencji obowiązuje zakaz ubiegania się o stanowiska w radzie municypalnej.

Jak zostało już wcześniej wspomniane, na gruncie prawa polskiego podstawową jednostką podziału terytorialnego jest gmina. Zgodnie z art. 1 i 2 ustawy o samorządzie gminnym, przez gminę należy rozumieć wspólnotę samorządową oraz odpowiednie terytorium. Gmina wykonuje zadania publiczne w imieniu własnym i na własną odpowiedzialność, posiada również osobowość prawną. W Polsce w przypadku gminy mamy organ stanowiący i kontrolny, którym jest rada gminy oraz organ wykonawczy, którym jest wójt (burmistrz, prezydent miasta). Wybory do organów stanowiących są powszechne, równe, bezpośrednie i odbywają się w głosowaniu tajnym.

Zgodnie z polską regulacją prawną do zakresu działania gminy należą wszystkie sprawy publiczne o znaczeniu lokalnym niezastrzeżone odrębnymi ustawami na rzecz innych podmiotów. Na tle regulacji meksykańskiej, polskie ustawodawstwo przewiduje rozróżnienie zadań własnych, zleconych i powierzonych gminy. Do zadań własnych gminy należy zaspokajanie potrzeb wspólnoty gminy. Obejmuje to sprawy m.in. ładu przestrzennego, gospodarki nieruchomościami, ochrony środowiska i przyrody oraz gospodarki wodnej, wodociągów i zaopatrzenia w wodę, lokalnego transportu zbiorowego, edukacji publicznej.

5. I. Burgoa, dz. cyt., s. 75.

6. Ustawa z dnia 8 marca 1990 r. o samorządzie gminnym (Dz. U. z 2018 r. poz. 994 z późn. zm.).

Miasto. Pamięć i Przyszłość 3/2 (2018) ISSN 2543-621X 
Odmienności trójstopniowego podziału terytorialnego Polski w zestawieniu z dwustopniowym podziałem terytorialnym Meksyku

Specyficzną jednostką podziału terytorialnego w Polsce są miasta na prawach powiatu. Organami w mieście na prawach powiatu są rada gminy i prezydent miasta. Miasta na prawach powiatu to gminy, które tym różnią się od innych gmin, że dodatkowo wykonują zadania powiatu. Skutkiem takiego rozwiązania jest przede wszystkim stosowanie do miast na prawach powiatu w pierwszej kolejności przepisów dotyczących gmin, natomiast przepisy dotyczące powiatów mają jedynie zastosowanie odpowiednie - tylko w zakresie, w którym miasta te wykonują zadania powiatu. Podstawą ustroju miasta na prawach powiatu jest - zgodnie z normami przyjętymi w ustawie o samorządzie gminnym - jego statut. Statut powinien określać przede wszystkim:

- organizację wewnętrzną oraz tryb pracy organów rady,

zasady tworzenia, łączenia, podziału oraz znoszenia jednostki pomocniczej,

zasady dostępu do dokumentów wynikających z wykonywania działań publicznych, w tym protokołów posiedzeń organów miasta i komisji miasta,

- $\quad$ zasady i tryb działania komisji rewizyjnej,

- zasady działania klubów radnych.

Ponadto, w przypadku, gdy miasto liczy ponad 300000 mieszkańców, statut podlega uprzedniemu uzgodnieniu z Prezesem Rady

Miasto. Pamięć i Przyszłość 3/2 (2018) ISSN 2543-621X
Ministrów. To właśnie prawo rady miasta do uchwalenia statutu, czyli możliwość determinowania sposobu funkcjonowania miasta na prawach powiatu, jest jednym z przymiotów samodzielności miasta, który został określony w art. 169 ust. 4 Konstytucji RP7.

Drugi rodzaj jednostek polskiego samorządu terytorialnego tworzą powiaty. Ich liczba wynosi obecnie 314. Ustawa o samorządzie powiatowym nie wprowadza przyjętego w ustawie o samorządzie gminnym podziału zadań jednostek samorządowych na zadania własne i zlecone z zakresu administracji rządowej. Odwołuje się w tym zakresie do generalnej zasady, iż ustawy szczególne mogą określać, które zadania będą wykonywane jako zadania z zakresu administracji rządowej ${ }^{8}$. Władzę w powiecie sprawuje rada powiatu jako organ stanowiący i kontrolny oraz zarząd powiatu jako organ wykonawczy, którego przewodniczącym jest starosta9. W związku z dwustopniowym podziałem terytorialnym Meksyku, nie znajdziemy tam odpowiedników polskich powiatów.

\section{Meksykańskie stany a polskie województwo}

Drugim, a zarazem ostatnim szczeblem struktury terytorialnej w Meksyku są stany ${ }^{10}$. Muszą one przyjąć republikańską, przedstawicielską

7. Z. Bukowski, T. Jędrzejewski, P. Rączka, Ustrój samorządu terytorialnego, Toruń 2013, s. 123.

8. Cz. Martysz, Podział zadań i kompetencji pomiędzy jednostkami samorządu terytorialnego ze szczególnym uwzględnieniem samorządowego powiatu i samorządowego województwa, [w:] Prawo administracyjne w okresie transformacji ustrojowej, red. E. Knosala, A. Matan, G. Łaszczyca, Kraków 1999, s. 225.

9. Ustawa z dnia 5 czerwca 1998 r. o samorządzie powiatowym (Dz. U. z 2018 r. poz. 955 z późn. zm.).

10. I. Burgoa, dz. cyt., s. 52. 


\section{Mapa 1 - mapa stanów w Meksyku}

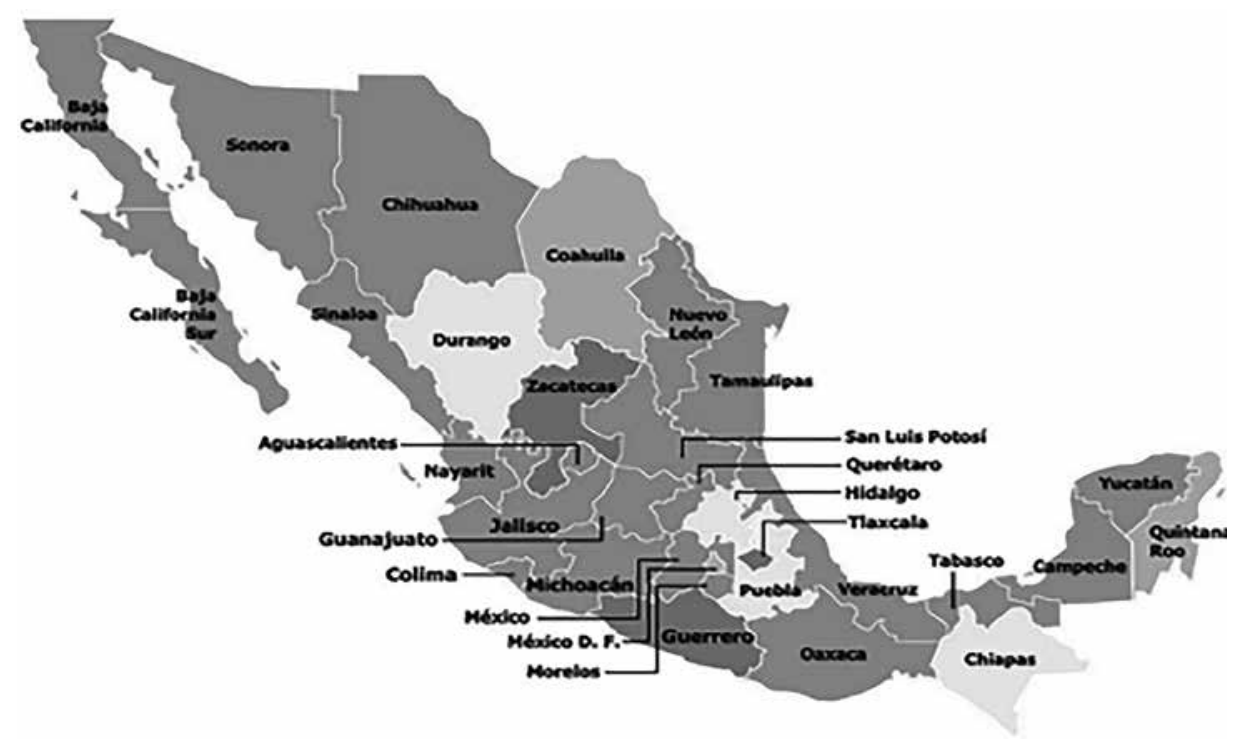

Źródło: www.histurion.pl

i ludową formę rządów. Dopiero w ramach tych zasad w sposób wolny i suwerenny mogą organizować zasady swojego ustroju wewnętrznego. Zgodnie z konstytucją, struktura władz stanowych oparta jest na podziale władzy. Władza wykonawcza została przekazana gubernatorom stanów, władza ustawodawcza - stanowym organom ustawodawczym, zaś władza sądownicza - sądom stanowym. Gubernatorzy, wybierani w wyborach powszechnych, bezpośrednich i tajnych, stoją na czele i kierują funkcjonowaniem administracji stanowej. Ich zadaniem jest wykonywanie ustaw federalnych i stanowionych przez legislatury stanowe.

Władza ustawodawcza w stanach należy do stanowych organów ustawodawczych. Zakres ich kompetencji obejmuje stanowienie ustaw we wszystkich materiach niezastrzeżonych dla Kongresu Generalnego oraz expressis verbis zakazanych przez konstytucję federalną.

Odrębna i wyłączona z federalnej władzy sądowniczej jest struktura sądów w poszczególnych stanach. Konstytucja federalna przesądza o funkcjonowaniu w stanach sądu najwyższego, strukturę i organizację innych sądów określają natomiast inne konstytucje stanowe, mające tworzyć również gwarancje niezależności sądów i sędziów.

Z mocy samej konstytucji władze stanów pozbawione są prawa podejmowania decyzji w materiach przez nią enumeratywnie wyliczonych. Do tych materii należy m.in. zawieranie 


\section{Mapa 2 - Województwa w Polsce}

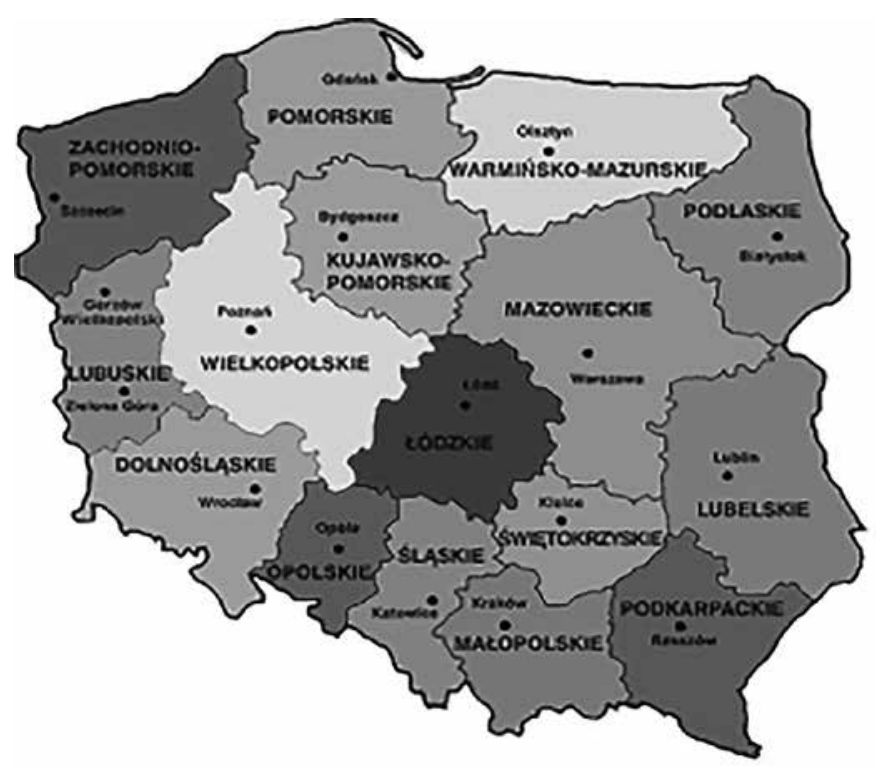

Źródło: www.mapy.net.pl

sojuszy i przymierzy oraz traktatów z innymi stanami oraz strukturami zagranicznymi, bicie własnej monety, utrudnianie wstępu komukolwiek na własne terytorium, zakazywanie lub wprowadzanie trudności w sferze nakładania ceł na towary wwożone na terytorium stanu, podejmowanie zobowiązań i zaciąganie pożyczek w innych państwach, organizacjach międzynarodowych, nawet u osób fizycznych (art. 117 Konstytucji) ${ }^{11}$.

W Polsce na trójstopniowy podział terytorialny składają się również województwa. Samorząd województwa jest to wyodrębniony i zasiedlający określone terytorium w strukturze państwa związek społeczności regionalnej funkcjonujący w randze województwa.

Miasto. Pamięć i Przyszłość 3/2 (2018) ISSN 2543-621X 33
Charakterystyczny dla województwa jest podział zadań pomiędzy administrację samorządową oraz terenową administrację rządową. Terenową administrację rządową w województwie tworzy wojewoda (jako przedstawiciel Rady Ministrów w województwie, zwierzchnik i organ rządowej administracji zespolonej w województwie), organy rządowej administracji zespolonej w województwie, w tym kierownicy zespolonych służb, inspekcji i straży. Według ustawy województwo to "regionalna wspólnota samorządowa oraz określone terytorium”'12. Zakres działania samorządu województwa nie narusza samodzielności powiatu i gminy. Organy samorządu województwa, którymi są sejmik województwa i zarząd województwa, nie stanowią

11. Tamże, s. 56

12. Ustawa z dnia 5 czerwca 1998 r. o samorządzie województwa (Dz. U. z 2018 r. poz. 913). 


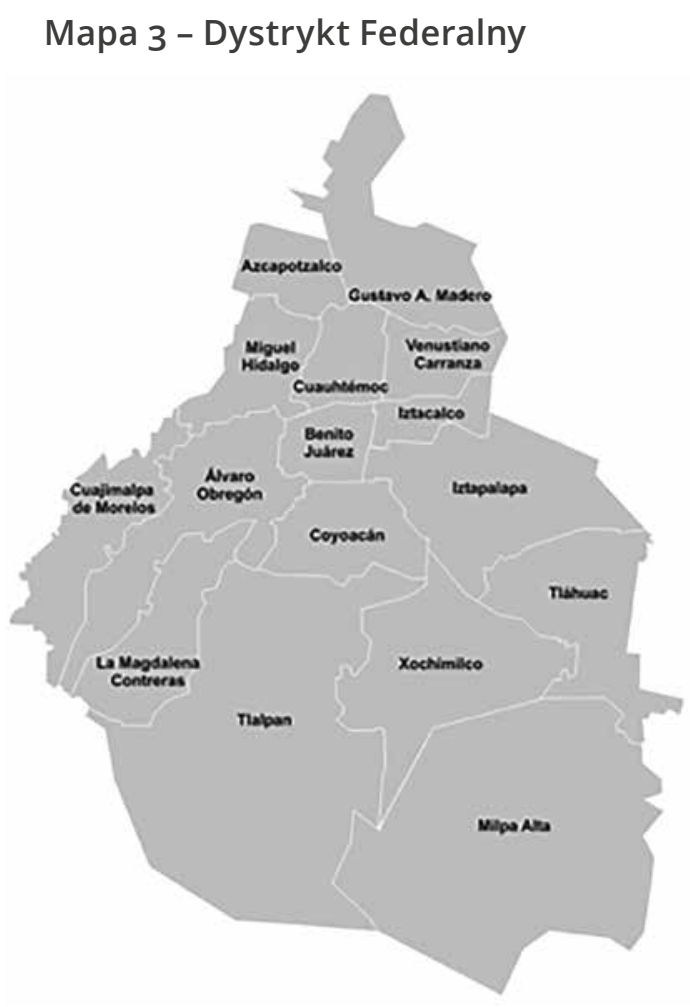

Źródło: www.pl.wikipedia.org.pl

wobec powiatu i gminy organów nadzoru lub kontroli. Województwo ma osobowość prawną, a jego ustrój określa statut uchwalony po uzgodnieniu z Prezesem Rady Ministrów.

Zadania samorządu terytorialnego obejmują zadania w zakresie m.in. edukacji publicznej, w tym szkolnictwa wyższego, promocji i ochrony zdrowia, kultury oraz ochrony zabytków i opieki nad zabytkami, pomocy społecznej, polityki prorodzinnej, modernizacji terenów wiejskich, zagospodarowania przestrzennego czy ochrony środowiska³.

\section{Miasto Meksyk}

Odrębną jednostką podziału terytorialnego Meksyku jest Miasto Meksyk. Z punktu widzenia statusu prawnego jest ono strukturą autonomiczną, zaś podstawę jego ustroju reguluje statut organiczny dystryktu federalnego. Władzę sprawują niezależne bezpośrednio od władz federacji organy lokalne. Należy do nich Zgromadzenie Ustawodawcze (Legislatura de la Ciudad de México), stanowiące w ramach swoich kompetencji ustawy obowiązujące na obszarze dystryktu. Władzę wykonawczą sprawuje Szef - Rządu Miasta Meksyk (Jefe de Gobierno de la Ciudad de México), zaś najwyższą instancją sądową jest Sąd Najwyższy Miasta Meksyk (Tribunal Superior de Justicia de la Ciudad de México). Konstytucja federalna autonomię Miasta Meksyk w znacznym stopniu ogranicza. W stolicy funkcjonuje wprawdzie system organów naczelnych, ale lokalne organy ustawodawcze i wykonawcze jedynie współuczestniczą w sprawowaniu władzy. O takiej ich roli przesądza art. 122 Konstytucji. Zgodnie z jego brzmieniem, władzę w stolicy sprawują wspólnie władze federalne oraz władze lokalne. W efekcie przyjęcia takiej konstrukcji, konstytucja federalna zabezpiecza na rzecz Kongresu Generalnego i prezydenta, istotne kompetencje, które wyznaczają zakres udziału obu władz federalnych we współrządzeniu stolicą ${ }^{14}$.

\section{Zakres ustawodawstwa}

Zgromadzenia Federalnego obejmuje następujące kwestie: opracowywanie i uchwalanie Miasto. Pamięć i Przyszłość 3/2 (2018) ISSN 2543-621X
13. J. Zim
s. 256 .

14. I. Burgoa, dz. cyt., s. 59. 
Tabela 1. Zestawienie podobieństw i różnic ustroju terytorialnego Meksyku i Polski

\begin{tabular}{|c|c|c|}
\hline & Podobieństwa & Różnice \\
\hline Polska & $\begin{array}{l}\text { - } \quad \text { województwo - obejmuje stosunkowo } \\
\text { _ } \quad \text { wojezy obszar } \\
\text { czeniu regionalnym } \\
\text { - } \quad \text { gmina realizuje zadania o znaczeniu } \\
\text { lokalnym }\end{array}$ & $\begin{array}{ll}\text { - } & \text { trójstopniowy podział } \\
& \text { terytorialny } \\
\text { - } & \text { powiaty } \\
\text { - } & \text { miasta na prawach powiatu }\end{array}$ \\
\hline Meksyk & $\begin{array}{ll}\text { - } & \text { stan - obejmuje stosunkowo duży } \\
& \text { obszar } \\
\text { - } & \text { stan realizuje zadania o znaczeniu } \\
& \text { regionalnym } \\
\text { - } & \text { municypium realizuje zadania o zna- } \\
& \text { czeniu lokalnym }\end{array}$ & $\begin{array}{ll}\text { - } & \text { dwustopniowy podział } \\
& \text { terytorialny } \\
\text { - } & \text { Miasto Meksyk } \\
\text { - } & \text { autonomia stanów }\end{array}$ \\
\hline
\end{tabular}

Źródło: opracowanie własne

budżetu, kontrolę wykonania budżetu, ustawodawstwo w sprawach cywilnych i karnych, powoływanie i organizowanie działania instytucji mającej stać na straży przestrzegania praw i wolności oraz planowanie rozwoju społecznego i gospodarczego.

Do zadań Szefa Rządu Miasta Meksyk należy natomiast obowiązek wprowadzania w życie i wykonywania ustaw uchwalanych przez Zgromadzenie Ustawodawcze Miasta Meksyk, korzystanie z inicjatywy ustawodawczej w zakresie materii należących do kompetencji Zgromadzenia Ustawodawczego, kierowanie funkcjonowaniem służb policyjnych i porządkowych oraz prawo nominacji na wszystkie stanowiska w administracji stolicy.

Miasto. Pamięć i Przyszłość 3/2 (2018) ISSN 2543-621X

\section{Zakończenie}

Prowadzona analiza prawnoporównawcza ustroju terytorialnego Polski i Meksyku umożliwia wskazanie różnic i podobieństw w zakresie podziału terytorialnego obu państw. Różnice zasadniczo wynikają z przyjęcia różnych modeli podziału terytorialnego, czyli modelu dwustopniowego w Meksyku i trójstopniowego w Polsce. W Polsce funkcjonują powiaty oraz specyficzne jednostki, jakimi są miasta na prawach powiatu, natomiast w Meksyku specyficzną jednostką podziału jest stolica. Jeżeli chodzi o województwa i stany, to jedynym podobieństwem jest to, iż obejmują one stosunkowo duży obszar i realizują zadania o znaczeniu regionalnym. Niemniej jednak, z uwagi na federacyjną strukturę 
Meksyku, należy podkreślić, iż stany w tym państwie zachowują pewną autonomię, a władza jest tam sprawowana na zasadzie trójpodziału.

Niewątpliwie znacznym podobieństwem jest to, że na najniższym szczeblu podziału występują jednostki terytorialne, obejmujące stosunkowo niewielki obszar. Jednostki te łączy również to, że zostały wydzielone w celu efektywniejszego wykonywania zadań o znaczeniu lokalnym.

\section{Literatura:}

- I. Burgoa, Derecho constitucional mexicano, Mexico 1979.

- Z. Bukowski, T. Jędrzejewski, P. Rączka, Ustrój samorządu terytorialnego, Toruń 2013.

- K. Complak, Artykuł41 Konstytucji Meksyku (brzmienie, objaśnienia, znaczenie), [w:] Dookoła Wojtek .... Księga pamiątkowa poświęcona Doktorowi Arturowi Wojciechowi Preisnerowi, red. R. Balicki, M. Jabłoński, Wrocław 2018

- B. Dolnicki, Samorząd terytorialny, Kraków 2012.

- Cz. Martysz, Podział zadań i kompetencji pomiędzy jednostkami samorząu terytorialnego ze szczególnym uwzględnieniem samorząowego powiatu i samorzadowego województwa, [w:] Prawo administracyjne w okresie transformacji ustrojowej, red. E. Knosala, A. Matan, G. Łaszczyca, Kraków 1999.

- J. Zimmermann, Prawo administracyjne, Warszawa 2006. 